than hindered by man's activities. Therefore, no hope can be entertained for the locust and grasshopper problem becoming less acute merely as a result of a general development of a country. The Conference suggested that particular attention should be paid in all future investigations to the influence on the life and ecology of locusts and grasshoppers of the various forms of human activity, such as agriculture, pastoral activity, deforestation, grass fires, etc.
All the aspects of the general theory of locust outbreaks, and most of the regional problems were discussed by the Conference, which embodied the results of discussions in twenty-five resolutions and four recommendations, based on the facts presented in the papers printed as appendixes to the proceedings, forming a large volume of nearly 500 pages.

The next, the Fifth International Locust Conference, will be held at Brussels in August this year.

\title{
Numerical Changes in the German Student Body
}

\author{
By Dr. E. Y. Hartshorne, jun., Tutor in Sociology, Harvard University
}

$\mathrm{O}^{\mathrm{F}}$ FFICIAL figures for the student body in the German Reich are available up to and in. cluding the academic year 1936-37. Frequent alteration in methods of classification and description have obscured the nature of some of the changes and make it difficult and sometimes impossible to interpret them. Only the less equivocal figures are here discussed. For the academic years 1932--33, 1933-34 and 1934-35, these are taken from the official Deutsche Hochschulstatistik, vols. 10-14; for 1935-36 from the official Die Deutschen Hochschulen vol. 1 (vol. 2 for 1936-37 either has not appeared or is inaccessible in the United States and Great Britain); for 1936-37 from the Statistisches Jahrbuch für das Deutsche Reich of 1937. There is reason to believe that the tendencies described below have continued in the academic year 1937-38.

In what follows there are included as 'students' all registered as such, except (a) 'auditors', that is those not committed to any definite course or examination, and (b) foreign students, except where specially indicated.

The decrease in the number of students is largely, but not entirely, conditioned by National Socialist policy. There are three obvious factors which have produced a fall in numbers. First, the number of young men in the German population of an age to enter the universities has probably fallen somewhat during these years. Secondly, since 1934 a limit has been set to the numbers admissible to a university education. Thirdly, Jews and so-called 'non-Aryans' have been practically excluded and the proportion of women students has been nominally fixed. The decrease, however, has been much sharper than can be explained by the action of these factors alone.

TABLE 1. NUMBERS OF STUDENTS IN ALL GERMAN Hochschulen (UNIVERSITIES, COILLEGES OF ENGINEERING, MINING AND AGRICULTURE, AND SCHOOLS FOR TEACHERS AND FOR CATHOLIC THEOLOGY)

\begin{tabular}{|c|c|c|c|}
\hline Winter Term & Men & Women & Both \\
\hline $1932-33$ & 97,576 & 18,578 & 116,154 \\
$1933-34$ & 91,263 & 15,501 & 106,764 \\
$1934-35$ & 76,961 & 12,132 & 89,093 \\
$1935-36$ & 70,462 & 10,976 & 81,438 \\
$1936-37$ & 57,672 & 9,410 & 67,082 \\
\hline
\end{tabular}

Thus in the winter term of 1936-37 the total number of students was only $5.7 \cdot 8$ per cent of the number enrolled before the National Socialist seizure of power in 1933. "Coming events cast their shadows before" since in the academic year 1932-33 this deoline had already begun.
In the field of science, the accompanying graph shows the development of enrolment for the major groups: (1) agriculture, (2) engineering, (3) natural sciences with mathematics, and (4) medical sciences.* The sharp decline of entry in the last three of these practical fields is puzzling. It is easily intelligible that the National Socialist emphasis on

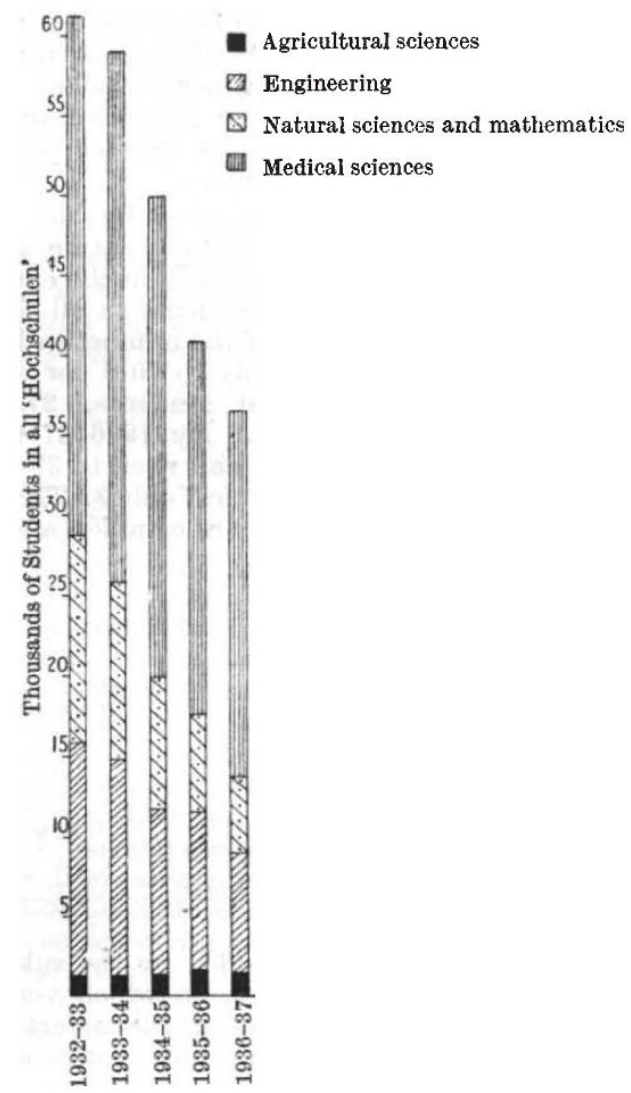

increased production from native soil should have raised the number in the agricultural sciences (1,356 in $1932-33$ to 1,477 in $1936-37)$ and also have raised the proportion of students of agriculture to the total entry of students (from $1 \cdot 2$ to $2 \cdot 2$ per cent).

* In the category of medical sciences are here included dentistry, veterinary surg $\mathrm{ry}$ and pharmacy. 
The numbers here involved are small. But it will surprise most readers that there should be a loss, both absolute and relative, in the number of students in the great departments of engineering and of the natural sciences. The number of students in certain science subjects are given in Table 2.

TABLE 2. STUDENTS OF SCIENCES OTHER THAN MEDICAL

\begin{tabular}{|c|c|c|c|}
\hline Winter Term & Engineering & $\begin{array}{c}\text { Mathematics } \\
\text { with Natural } \\
\text { Sciences }\end{array}$ & $\begin{array}{c}\text { Chemistry } \\
\text { only }\end{array}$ \\
\hline $\mathbf{1 9 3 2 - 3 3}$ & $\mathbf{1 4 , 4 7 7}$ & $\mathbf{1 2 , 9 5 1}$ & 3,543 \\
$\mathbf{1 9 3 3 - 3 4}$ & $\mathbf{1 3 , 4 5 2}$ & $\mathbf{1 0 , 8 5 2}$ & $\mathbf{7 , 5 0 4}$ \\
$\mathbf{1 9 3 4 - 3 5}$ & $\mathbf{1 0 , 3 1 0}$ & $\mathbf{7 , 9 4 3}$ & 3,006 \\
$\mathbf{1 9 3 5 - 3 6}$ & $\mathbf{9 , 2 9 3}$ & $\mathbf{6 , 4 9 3}$ & $\mathbf{2 , 6 9 6}$ \\
$\mathbf{1 9 3 6 - 3 7}$ & $\mathbf{7 , 6 4 9}$ & $\mathbf{4 , 6 1 6}$ & $\mathbf{2 , 0 5 8}$ \\
Percentage change & $\mathbf{5 2 \cdot 9}$ & $35 \cdot 6$ & $\mathbf{5 8} \cdot 0$ \\
\hline
\end{tabular}

Rearmament has naturally increased opportunities for the employment of highly-trained engineers, chemists, etc. Nevertheless, the flight from university education in these subjects is unmistakable. There are no reliable statistics to show the extent to which the great engineering and chemical concerns are training men on their own account and thus replacing the universities but, for certain departments of science, it is difficult to believe that they can provide courses that are adequate substitutes for those in universities. The greater part of the loss in numbers in these subjects, as in the general student body, is probably related to the more numerous and more tempting opportunities and the greater prestige of the expanding fighting services.

A peculiar position is occupied by the medical sciences. These show a large relative increase, though a considerable absolute fall, in the enrolment. While the total number of students in all fields fell in 1936-37 to $57 \cdot 8$ per cent of the number in 1932-33, in the medical field it fell only to $70 \cdot 2$ per cent. In 1932-33, of every hundred students, 27.9 were entered for medical courses. By 1936-37 the percentage of medical students had risen to 33.9 of the whole student body, as shown in Table 3. The factors at the back of these changes are complex and would need special discussion.

Table 3. STUdents on Medical sciences

\begin{tabular}{|c|c|c|}
\hline Winter Term & Total & $\begin{array}{c}\text { Percentage of Whole } \\
\text { Student Body }\end{array}$ \\
\hline $1932-33$ & 32,437 & - \\
$1933-34$ & 33,482 & - \\
$1934-35$ & 30,123 & - \\
$1935-36$ & 28,383 & $33 \cdot 9$ \\
$1936-37$ & 22,797 & \\
Percentage change & $70 \cdot 2$ & \\
\hline
\end{tabular}

Unexpected results are yielded by the subjects of 'race science' and pre-history, on which very great emphasis is laid in schools and in the general educational system. So far as the universities are concerned, these special fields have neither enlisted more than a very small number of native students nor have they attracted any foreign students. For "Vorgeschichte" there were only 59 native and no foreign students, and for "Rassenkunde" there were only 47 natives and one foreign student in 1934-35. After that academic year the numbers of students for these subjects disappear from the available statistics.
In fields other than those of the sciences we note the changes shown in Table 4.

TABLE 4. Students in NON-SCIENTIFIC FIELDS

\begin{tabular}{|c|c|c|c|c|}
\hline & & $1932-33$ & $1936-37$ & $\begin{array}{l}\text { Percentage } \\
\text { of } 1932-33 \\
\text { enrolment }\end{array}$ \\
\hline $\begin{array}{l}\text { Ancient languages } \\
\text { Modern languages } \\
\text { 'Germanistik' } \quad \text {. } \\
\text { Architecture } \quad \text {. } \\
\text { Journalism } \\
\text { Catholic theology } \\
\text { Protestant theology } \\
\text { Education }\end{array}$ & \begin{tabular}{l|}
$\because$ \\
$\because$ \\
$\because$ \\
$\cdots$ \\
$\cdots$ \\
$\cdots$ \\
.
\end{tabular} & $\begin{array}{l}1,225 \\
3,589 \\
3,636 \\
2,378 \\
208 \\
4,208 \\
6,588 \\
5,831\end{array}$ & $\begin{array}{r}307 \\
842 \\
1,540 \\
1,120 \\
353 \\
4,775 \\
2,583 \\
8,317\end{array}$ & $\begin{array}{r}25 \cdot 1 \\
23 \cdot 4 \\
42 \cdot 4 \\
47 \cdot 1 \\
169 \cdot 7 \\
113 \cdot 5 \\
39 \cdot 2 \\
142 \cdot 5\end{array}$ \\
\hline
\end{tabular}

In 'Education' the number of women is practially stationary. The increase in that department has been almost entirely of men. It is perhaps explained by the need for 'leaders' in various youth movements.

Foreign students are numerically unimportant though they are significant in other ways. The numbers of foreign students have been fairly maintained for agriculture $(97 \cdot 5$ per cent) and chemistry $(\mathbf{9 4} \cdot 3$ per cent). There have been moderate falls in engineering (to 86.2 per cent) and architecture (to $80 \cdot 3$ per cent). There are much greater falls in law and social sciences (to $65 \cdot 6$ per cent), medicine (to $55 \cdot 2$ per cent), ancient languages (to $42 \cdot 6$ per cent) and 'Education' (to so low as $\mathbf{1 2} \cdot \mathbf{7}$ per cent). The fall in the total number of foreign students is from 6,693 in 1932-33 to 4,768 in $1936-37$. The latter figure is 71.4 per cent of the former which is less change than might perhaps have been anticipated. The published figures do not permit us to determine the countries of origin of foreign students. We can say, however, that there has been a significant fall in English-speaking American students (from 817 to 418 , that is, to $5 \mathrm{I} \cdot 1$ per cent) and a significant rise in Spanish- and Portuguese-speaking American students (from 102 to 165 , that is, to 161.8 per cent).

Of all the major fields the greatest absolute loss has been in law and the social sciences. Yet despite this loss the Nationalist Socialist interpretation of these subjects is attracting the attention of certain foreign students as the figures in Table 5 show :

Table 5. Students of Law and Social Sciences.

\begin{tabular}{|c|c|c|}
\hline Winter Term & Ferman Reich Students & Foreign Students \\
$1932-33$ & 24,161 & 1070 \\
$1933-34$ & 20,363 & 669 \\
$1934-35$ & 15,291 & 621 \\
$1935-36$ & 12,617 & 651 \\
$1936-37$ & 9,680 & 702 \\
Percentage change & $40 \cdot 1$ & $65 \cdot 6$ \\
\hline
\end{tabular}

On the other hand, for medicine, Germany is ceasing to attract foreign students as is revealed in Table 6.

TABLE 6. FOREIGN STUDENTS OF MEDICAL SCIENCES

\begin{tabular}{|c|c|c|}
\hline Winter Term & German Reich Students & Foreign Students \\
\hline $1932-33$ & 32,437 & 1977 \\
$1933-34$ & 33,482 & 1249 \\
$1934-35$ & 30,123 & 1196 \\
$1935-36$ & 28,383 & 1172 \\
$1936-37$ & 22,797 & 1090 \\
Percentage change & $70 \cdot 2$ & $55 \cdot 2$ \\
\hline
\end{tabular}

